\title{
Enzyme addition to corn and soybean meal-based diets: Effect on performance and carcass composition of guinea fowl (Numida meleagris) broilers ${ }^{1,2}$
}

\author{
Héctor L. Santiago ${ }^{3}$, José A. Orama ${ }^{4}$ and Abner A. Rodríguez ${ }^{5}$
}

J. Agric. Univ. P.R. 94(3-4):237-246 (2010)

\begin{abstract}
Recent studies have demonstrated the benefits of supplementation of broiler chick diets based on corn and so ybean meal with enzymes suc $h$ as amylases and proteases. However, these benefits cannot necessarily be extrapolated to the commer cial production of other species of domestic animals. The objective of this study was to determine the effects of diet fortification with A vizyme $\AA$ (AV) on guinea br oiler growth performance and processing yields. Six hundred guinea keets, randomly assigned to $f$ our treatments with 10 replications of 15 bir ds per pen, were reared under a three-phase feeding regime until market age (84 d) in a conventional poultry house. Treatments consisted of diets containing 0 (control), $0.025,0.050$, and $0.075 \%$ of AV. Birds and feed were weighed weekly until $84 \mathrm{~d}$ of age to determine body weight (BW), feed intake (FI), and feed conversion ratio (FCR). Dead and culled bir ds (CB) were remo ved and weighed dail y. At $84 \mathrm{~d}, 50$ birds per treatment were pr ocessed to e valuate carcass composition. The weights of carcass (CW), fat pad (FP) and car cass parts were obtained and yields were calculated as a percentage of live BW. No differences in BW, mortality, $C B$ and $C W$ were $f$ ound among treatments. The yields of car cass, breast, drumsticks, thighs, and FP were similar $f$ or all dietar $y$ treatments evaluated. Results at 35,63 and $84 \mathrm{~d}$ were mixed, but in general birds fed diets containing AV exhibited lower $(P<0.01) \mathrm{FI}$ and FCR than control birds. At $84 \mathrm{~d}$, birds fed $0.025 \%$ AV diets had lower $(P<0.01)$ FI and FCR than contols. These data sug gest that supplementation with corn and so ybean mealbased diets with at least $0.025 \%$ of AV improves FCR of guinea broilers without affecting $B W$ at market age nor carcass composition.
\end{abstract}

Key words: avizyme, guinea, performance, yields

\section{RESUMEN}

La adición de enzimas a dietas basadas en maíz y harina de soya y el desempeño productivo y la composición de la canal de guineas (Numida meleagris) de engorde

${ }^{1}$ Manuscript submitted to Editorial Board 27 October 2010.

2This project was funded by a grant from the UPR-AES (SP-385).

${ }^{3}$ Associate Researcher, Department of Animal Industry, Agricultural Experiment Station, University of Puerto Rico-Mayagüez, Call Box 9000, Mayagüez, P.R. 00681-9000.

${ }^{4}$ Graduate Student, Department of Animal Industry.

${ }^{5}$ Professor, Department of Animal Industry. 
Estudios recientes han demostrado los beneficios de la suplementación con enzimas como amilasas y pr oteasas en dietas para pollos de engor de basadas en maíz y harina de soya. Sin embargo, estos beneficios no necesariamente pueden ser extrapolados a la producción comercial de otras especies de animales domésticos. El objetivo de este estudio fue determinar los efectos de la fortificación dietética con Avizyme $\otimes$ (AV) sobre el crecimiento y rendimiento de procesado de guineas de engor de. Seiscientos pollos de guineas de engorde, asignados al azar a cuatro tratamientos con 10 repeticiones de 15 aves por jaula, se criaron bajo un régimen de alimentación trifásica hasta la edad de mer cado (84 d) en un galpón de cría con vencional. Los tratamientos consistier on en dietas que contenían 0 (Contr ol), $\mathbf{0 . 0 2 5}$, 0.050 y $0.075 \%$ de AV. Semanalmente se pesó el alimento y las ares, hasta alcanzar los $84 \mathrm{~d}$ de edad, para determinar el peso corporal (PC), consumo de alimento (CA) y la razón de conversión de alimento (RCA). Las aves muertas y rezagadas (AR) se remo vieron y se pesar on diariamente. A los $84 \mathrm{~d}$ de edad, se procesaron $\mathbf{5 0}$ aves por tratamiento para evaluar las características de la canal, obteniéndose los pesos de la canal (PCN),grasa abdominal (GA) y partes de la canal; los rendimientos se calcularon como un porcentaje del peso vivo. No se observaron diferencias entre tratamientos para $\mathrm{PC}$, mortalidad, AR ni PCN. Los rendimientos de canal, pechuga, muslos, caderas y GA fueron similares para todos los tratamientos e valuados. Los resultados para $C A$ a los 35,63 y 84 d de edad fuer on mixtos, pero en general las aves suplementadas con AV exhibieron menor $(P<0.01)$ CA y RCA que las guineas control. A los $84 \mathrm{~d}$, las aves alimentadas con la adición dietética de $0.025 \%$ de AV obtuvieron menores CA y RCA $(P<0.01)$ que las aves control. Estos datos sugieren que la adición de al menos un $0.025 \%$ de $\mathrm{AV}$ a dietas a base de soya y maíz mejora la conversión de alimento de gallinas de guinea de engorde sin afectar el PC a la edad de mecado ni la composición de la canal.

Palabras clave: Avizyme, guinea, desempeño, rendimientos

\section{INTRODUCTION}

The addition of enzymes to poultry diets, having been found beneficial, has become a common practice in diets containing carbohydrates or protein sources with high levels of non starc $h$ polysaccharides such as wheat and barley (W aldroup et al., 2002). New technologies have been developed to improve digestibility of cereal grain starch and vegetable protein in poultry diets based principally on corn and soybean meal. Danisco Animal Nutrition has developed Avizyme $1502^{6}$ specifically for use in poultry diets containing low viscosity grains suc $h$ as corn and sorghum, and also significant levels of soybean meal Avizyme is a multi-enzyme product containing amylase (whic $\mathrm{h}$ improves corn starch utilization), xylanase (which breaks down cereal cell walls), and protease (which targets soybean antinutritional factors and storage proteins). Several researchers have reported that the use of this prod-

${ }^{6}$ Company or trade names in this publication are used only to provide specific infor mation. Mention of a company or trade name does not constitute a $w$ arranty of equipment or materials by the Agricultural Experiment Station of the University of Puerto Rico, nor is this mention a statement of preference over other equipment or materials. 
uct can significantly increase energy protein, and amino acid (methionine, lysine, cysteine, and threonine) utilization in corn and soybean meal-based diets (Café et al., 2002; Douglas et al., 2000; Waldroup et al., 2002; Zanella et al., 1999).

Café et al.(2002) reported that broilers fed diets supplemented with $0.10 \%$ Avizyme had greater BW and less mortality up to $49 \mathrm{~d}$ of age than the controls. The abdominal fat content of the carcass was greater in birds fed diets supplemented with Avizyme than in controls, but no consistent effect was observed in dressing percentage or yield of carcass parts. These authors suggested that the utilization of Avizyme increased the amount of net energy supplied by the diet. Avizyme might reduce feed costs and maintain broiler performance by improving the FCR and by reducing the variability of liveweight in a floc $\mathrm{k}$ (Avizyme 1500 Technical Bulletin, 2002). This outcome might result from improved digestibility of crude protein $(+2.9 \%)$, starch $(+1.8 \%)$, and fat $(+1.6 \%)$, and by enhanced metabolizable energy value $(+2.5 \%)$ of corn and soybean-meal based diets (Zanella et al.,1999). These authors also reported that the addition of $0.10 \%$ of Avizyme significantly improved BW gain and FCR, but caused no significant effects on abdominal fat, breast weight, or dressing percentage. The addition of Avizyme to sorghum and soybean meal diets has produced inconsistent effectsFor example, in one investigation this enzyme addition improved liveweight corrected FCR by five to 16 points over that of three experiments, and reduced dietary nutrient requirements by $3 \%$ while maintaining broiler performance (Wyatt et al., 1997). Another investigation, however, showed that the addition of $0.10 \%$ of Avizyme to broiler diets had no significant effect on weight gain or FCR (Douglas et al., 2000).

To our knowledge, no research has been conducted on the addition of Avizyme to guinea fowl (Numida meleagris) diets. The results from conventional broiler studies suggest that the utilization of this enzyme complex in guinea fowl diets might improve productive performance and potentially benefit producers. Therefore, the objective of this research was to determine the effects of Avizyme supplementation to nutritionally adequate diets based on corn and soybean meal-effects upon live performance and carcass composition of guinea fowl broilers.

\section{MATERIALS AND METHODS}

Six hundred one-day-old guinea keets were raised under standard commercial conditions in a conventional poultry house at the SmalAnimal Research Farm of the Agricultural Experiment Station in Lajas, Puerto Rico. A 24-h photo regimen w as used and ad-libitum access to feed and water was provided. Keets were randomly assigned to 40 floor 
pens ( 15 keets per pen) with 10 replicate pens per treatment, and placed at a stoc king density of $0.10 \mathrm{~m}^{2}$ in rice sha ving-bedded pens equipped with one hanging tube feeder and nipple type drinkersTreatments (experimental diets) consisted of the addition ofAvizyme 1502 at 0 (control), $0.025,0.050$, and $0.075 \%$ to basal diets during the starter, grower, and finisher phases. Basal diets were corn and soybean-based and formulated to meet or exceed the nutrient requirements for guineas published earlier (Oguntona et al., 1988; Oguntona and Zubair, 1988; Mandal et al., 1999). The successive phases of the feeding regime took place from 0 to $5 \mathrm{wk}, 6$ to $9 \mathrm{wk}$, and 10 to $12 \mathrm{wk}$.This type of regime has been recommended by Hughes and J ones (1980), Oguntona et al. (1988), and Oguntona and Zubair (1988). The enzyme source was preblended with a portion of the basal diet before total incorporation into the respective diets in mash form. All ingredients were analyzed for chemical composition prior to diet formulation. Table 1 shows the ingredients and theoretical nutrient compositions of the basal diets.

TABLE 1.-Percentage composition and nutrient content of the basal diets.

\begin{tabular}{lccc}
\hline & $\begin{array}{c}\text { Starter } \\
(0-5 \mathrm{wk})\end{array}$ & $\begin{array}{c}\text { Grower } \\
(6-9 \mathrm{wk})\end{array}$ & $\begin{array}{c}\text { Finisher } \\
(10-12 \mathrm{wk})\end{array}$ \\
\hline Ingredient (\%) & & & \\
Ground corn & 50.02 & 53.33 & 60.00 \\
Soybean meal & 41.74 & 33.00 & 27.68 \\
Vegetable oil & 3.65 & 6.31 & 6.37 \\
Dicalcium phosphate & 1.75 & 1.58 & 1.51 \\
Vitamin and mineral premix ${ }^{1}$ & 0.50 & 0.50 & 0.50 \\
Limestone & 1.74 & 1.80 & 1.41 \\
DL-Methionine & 0.10 & 0.01 & 0.03 \\
Salt & 0.50 & 0.50 & 0.50 \\
Calculated Contents & & & \\
CP (\%) & 24 & 20 & 18 \\
ME (kcal/kg) & 3,050 & 3,180 & 3,280 \\
Crude fat (\%) & 5.78 & 8.44 & 8.69 \\
Crude fiber $(\%)$ & 2.20 & 2.00 & 1.97 \\
Ca (\%) & 1.10 & 1.07 & 0.90 \\
Total P (\%) & 0.72 & 0.64 & 0.61 \\
Methionine (\%) & 0.48 & 0.34 & 0.33 \\
Cysteine (\%) & 0.39 & 0.33 & 0.30 \\
Lysine (\%) & 1.38 & 1.12 & 0.98 \\
\hline
\end{tabular}

${ }^{1}$ Composition of vitamin-mineral premix provided per kilogram of diet: $\mathrm{Fe}, 60 \mathrm{mg} ; \mathrm{Cu}$, $5 \mathrm{mg}$; Zn, $51.4 \mathrm{mg}$; Mn, $60.8 \mathrm{mg}$; Se, $0.2 \mathrm{mg}$; I, $0.6 \mathrm{mg}$; vitamin A, 12,000 IU; cholecalciferol, $3,000 \mathrm{IU}$; vitamin $\mathrm{E}, 49 \mathrm{IU}$; vitamin B1, $2.1 \mathrm{mg}$; vitamin $\mathrm{B} 2,6.6 \mathrm{mg}$; vitamin $\mathrm{B} 6,4.1 \mathrm{mg}$; vitamin $B_{12}, 20.7 \mu g$; pantothenic acid, $15 \mathrm{mg}$; nicotinic acid, $36 \mathrm{mg}$; folic acid, $1 \mathrm{mg}$; biotin, $102 \mathrm{mg}$; choline chloride, $700 \mathrm{mg}$; ethoxyquin, $120 \mathrm{mg}$. 
The birds were routinely checked twice a day, and the weight of mor talities was recorded and used to adjust the feed conversion ratio (FCR). Birds and feed were weighed once a week until 12 wk of age to calculate bodyweight (BW), feed intake (FI), and FCR. At 12 wk of age, 200 birds were processed to determine carcass characteristics. The day prior to processing, five individuals per replicate pen, for a total of 50 birds per treatment, were randomly selected, wing banded, weighed, and placed in coops $10 \mathrm{~h}$ prior to slaughter, without access to feed and water. Birds were hung in metallic funnels and killed by bleeding from a single cut severing the carotid artery and jugular vein. After exanguination, the bodies were scalded, mechanically plucked, weighed, and manually eviscerated. Carcasses were chilled overnight in an iceslush tank maintained at a temperature of $0^{\circ} \mathrm{C}$ for $24 \mathrm{~h}$.After chilling, carcasses were drained, reweighed, and cut into the following portions: wings, drumsticks, thighs, breast with ribs, back, and neck. Carcass parts and abdominal fats were weighed; yields were expressed as percentage of live body weight. The breasts, drumsticks, and thighs were further separated into skin, meat, and bone. The total weight of each portion was recorded to the nearest gram, and yield was expressed as a proportion of carcass weight.

Treatments were replicated 10 times and arranged in a complete randomized design. Each pen of 15 keets constituted an experimental unit. Treatment differences were determined by analysis of variance (ANOVA) utilizing SAS /GLM software. Treatment means of variables showing significant differences in the ANOVA were ranked by using Tukey's multiple comparison test option of SAS . Analyses were performed by using Version 9.1 of the SAS System for Windows (SAS Institute Inc., Cary, NC, USA). All statements of significance are based on a probability level of 0.05 unless otherwise indicated.

\section{RESULTS AND DISCUSSION}

Growth rate of guinea fowl broilers w as not influenced by addition of Avizyme to the basal diets . Birds fed diets containing Avizyme had BW at the end of each growth phase similar to those of birds receiving the control diet (Table 2). These results contrast with the findings of Café et al. (2002) and Zanella et al. (1999), who reported significantly higher BW in broilers fed diets containing Avizyme. Differences among dietary treatments were observed for FI. At $35 \mathrm{~d}$ of age, birds receiving diets containing 0.025 and $0.050 \%$ $\mathrm{AV}$ had similar but significantly lower $(\mathrm{P}<0.01)$ FI than the controls, whereas those fed a $0.075 \% \mathrm{AV}$ diet had FI similar to that of the rest of the treatments. At the end of the grower phase ( $63 \mathrm{~d})$, 
TABLE 2.-Live performance of guinea broilers receiving diets with increasing levels of Avizyme.

\begin{tabular}{|c|c|c|c|c|c|c|}
\hline \multirow[b]{2}{*}{ Age (d) } & \multicolumn{4}{|c|}{ AV level of inclusion $(\%)$} & \multirow[b]{2}{*}{ SEM } & \multirow[b]{2}{*}{ Probability } \\
\hline & Control & 0.025 & 0.050 & 0.075 & & \\
\hline \multicolumn{7}{|c|}{ Cumulative body weight (g) } \\
\hline 1 & 31 & 30 & 30 & 30 & 1.32 & 0.56 \\
\hline 35 & 672 & 676 & 672 & 671 & 27.7 & 0.98 \\
\hline 63 & 1,489 & 1,499 & 1,472 & 1,508 & 54.3 & 0.50 \\
\hline 84 & 1,910 & 1,918 & 1,919 & 1,931 & 46.0 & 0.80 \\
\hline \multicolumn{7}{|c|}{ Cumulative feed intake ( $\mathrm{g}$ ) } \\
\hline 35 & $1,534 \mathrm{a}^{1}$ & $1,220 \mathrm{~b}$ & $1,290 \mathrm{~b}$ & $1,309 \mathrm{ab}$ & 187 & 0.01 \\
\hline 63 & $4,507 \mathrm{a}$ & $3,897 \mathrm{~b}$ & $4,069 \mathrm{~b}$ & $4,002 \mathrm{~b}$ & 282 & 0.01 \\
\hline 84 & $6,882 \mathrm{a}$ & $6,243 \mathrm{~b}$ & $6,592 \mathrm{ab}$ & $6,497 \mathrm{ab}$ & 395 & 0.03 \\
\hline \multicolumn{7}{|c|}{ Cumulative feed conversion ( $\mathrm{g}$ feed $/ \mathrm{g} B W$ ) } \\
\hline 35 & $2.40 \mathrm{a}$ & $1.89 \mathrm{~b}$ & $2.01 \mathrm{~b}$ & $2.04 \mathrm{~b}$ & 0.25 & 0.01 \\
\hline 63 & $3.11 \mathrm{a}$ & $2.65 \mathrm{~b}$ & $2.81 \mathrm{~b}$ & $2.72 \mathrm{~b}$ & 0.18 & $<0.00$ \\
\hline 84 & $3.68 \mathrm{a}$ & $3.29 \mathrm{~b}$ & $3.47 \mathrm{ab}$ & $3.40 \mathrm{~b}$ & 0.18 & 0.00 \\
\hline
\end{tabular}

${ }^{1}$ Within rows, means with different letters are significantly different $(\mathrm{P} \leq 0.05)$.

birds receiving all three diets fortified with Avizyme had less $(\mathrm{P}<$ $0.01)$ FI than the controls. At market age ( $84 \mathrm{~d})$, FI was lower in birds fed diets containing $0.025 \% \mathrm{AV}(\mathrm{P}<0.01)$ than in the controls, whereas FI of birds receiving $0.050 \%$ and $0.075 \%$ AV was statistically similar to that of the rest of the dietary treatments. At 35 and $63 \mathrm{~d}$ of age, birds fed diets with added Avizyme demonstrated lower FCR than that of the controls At 84 d, only birds receiving diets containing $0.025 \%$ AV had lower $(\mathrm{P}<0.01)$ FCR than controls, whereas the use of higher levels ofAV did not significantly improve FCR.The use of Avizyme supplementation improved FCR relative to the control treatment by margins of $0.47,0.32$, and 0.29 conversion points during the successive starter, grower, and finisher periods. As reported in other research with feed enzymes, the response to the addition of Avizyme to broiler diets $w$ as also inconsistent in the present case. Wyatt et al. (1997) reported that supplementation of Avizyme to sorghum and soybean meal-based diets improved FCR by five to 16 percentage points and allowed a dietary nutrient reduction of $3.0 \%$ without adversely affecting growth performance Zanella et al. (1999) conducted two broiler performance trials on the addition of $0.10 \%$ of $\mathrm{AV}$ and obtained improved $\mathrm{BW}$ gain and FCR in one trial but no significant effect in the second trial. Moreover, Douglas et al. (2000) reported that the addition of $0.10 \%$ ofAV to broiler diets did not significantly improve weight gain or FCR. 
In the present research, although results were mixed, birds fed diets with added Avizyme demonstrated consistently lower FI and FCR than those fed the control diet. However, these improvements in feed efficiency were not accompanied by BW differences during any of the rearing phases evaluated.

The addition of AV to guinea broiler diets had no effect on percentage of mortality and culls (Table 3). Café et al. (2002) reported that diets formulated to contain $0.10 \% \mathrm{AV}$ reduced broiler mortality at 16,35 and $42 \mathrm{~d}$ of age when compared to mortality of birds fed the unsupplemented diet. Contrary to literature cited on conventional broilers, the present levels of addition of Avizyme to diets for guinea broilers had no significant effect on live BW, carcass, and fat pad yields (Table 4). Likewise, no differences in yields of carcass , breast, drumsticks, thighs, neck, and abdominal fat expressed as percentage of live BW were observed (Table 4). However, there were small and inconsistent differ ences in the yield of wings and bac $k$ among dietary treatments. Although differences were not significant, there was a linear increase in live BW, carcass weight, and carcass yield with increasing levels of Avizyme addition to the diets. Café et al. (2002) reported that broilers supplemented with $0.10 \%$ AV had increased carcass yield and increased proportion of abdominal fat at $42 \mathrm{~d}$ of age . In two broiler performance trials Zanella et al. (1999) observed that fortification with Avizyme had no significant effect on abdominal fat, breast weight or dressing percentage.

Table 5 shows the yields of body parts, meat, skin, bone, and fat as a percentage of carcass weight of guinea fowl broilers receiving diets with various concentrations of Avizyme. Among treatments, there were no differences in the yield of total and dark deboned meat, although these yields tended to decrease as the level ofAvizyme increased in the diet. Total deboned white meat yield was greater in birds fed a control diet than in those fed diets with $0.050 \%$ AV. Café et al. (2002) reported

TABLE 3.-Effect of increasing dietary level of Avizyme for guinea broilers on mortality and culled percentages.

\begin{tabular}{lcc}
\hline Treatment & Mortality $(\%)$ & Culls $(\%)$ \\
\hline Control & $0.00^{1}$ & 2.00 \\
$0.025 \% \mathrm{AV}$ & 2.00 & 0.67 \\
$0.050 \% \mathrm{AV}$ & 0.74 & 1.48 \\
$0.075 \% \mathrm{AV}$ & 0.74 & 2.22 \\
SEM & 2.25 & 3.34 \\
Probability & 0.27 & 0.74 \\
\hline
\end{tabular}

${ }^{1}$ Within columns, means followed by different letters are significantly different ( $\mathrm{K} 0.05$ ). 
TABLE 4.-Live and carcass weight and yield of body parts as a percentage of live body weight of guinea $f$ owl broilers receiving diets $w$ ith increasing levels of Avizyme.

\begin{tabular}{|c|c|c|c|c|c|c|c|c|c|c|}
\hline \multirow{2}{*}{$\begin{array}{l}\text { AV level of } \\
\text { inclusion }(\%)\end{array}$} & \multicolumn{2}{|c|}{ Weight (g) } & \multicolumn{8}{|c|}{ Percentage of live body weight $(\%)$} \\
\hline & Live $^{1}$ & Carcass $^{2}$ & Carcass & Breast & Wings & Drumstick & Thighs & Neck & Back & Abdominal fat \\
\hline 0 & 1,860 & 1,358 & 71.8 & 23.6 & $9.5 \mathrm{ab}^{3}$ & 9.3 & 12.0 & 4.4 & $16.7 \mathrm{ab}$ & 1.1 \\
\hline 0.025 & 1,890 & 1,379 & 71.8 & 22.6 & $9.6 \mathrm{ab}$ & 9.2 & 11.9 & 4.4 & $17.9 \mathrm{a}$ & 1.0 \\
\hline 0.050 & 1,885 & 1,377 & 72.5 & 22.3 & $9.9 \mathrm{a}$ & 9.6 & 12.9 & 4.4 & $16.5 \mathrm{~b}$ & 1.0 \\
\hline 0.075 & 1,918 & 1,412 & 73.9 & 24.1 & $9.4 \mathrm{~b}$ & 9.0 & 12.5 & 4.3 & $17.2 \mathrm{ab}$ & 1.1 \\
\hline SEM & 150.8 & 119.7 & 1.79 & 1.66 & 0.52 & 0.57 & 1.11 & 0.59 & 1.07 & 0.51 \\
\hline Probability & 0.29 & 0.18 & 0.08 & 0.08 & 0.05 & 0.16 & 0.12 & 0.67 & 0.02 & 0.14 \\
\hline
\end{tabular}

${ }^{1}$ Live body weight after $12 \mathrm{~h}$ of feed and water deprivation.

${ }^{2}$ Eviscerated weight after chilled for $24 \mathrm{~h}$.

${ }^{3}$ Within columns, means with different letters are significantly different $(\mathrm{P} \leq 0.05)$. 
TABLE 5.-Yield of body parts, meat, skin, bone and fat as a percentage of carcass weight of guinea $f \quad$ owl broilers receiving diets with increasing levels of Avizyme.

\begin{tabular}{|c|c|c|c|c|c|c|c|c|c|c|}
\hline \multirow{2}{*}{$\begin{array}{l}\text { AV level of } \\
\text { inclusion }(\%)\end{array}$} & \multicolumn{10}{|c|}{ Percentage of carcass weight ${ }^{1}(\%)$} \\
\hline & Wings & Legs & Breast & Neck plus back & Total meat & White $^{2}$ meat & $\operatorname{Dark}^{3}$ meat & Skin $^{4}$ & Bone $^{5}$ & Abdominal Fat ${ }^{6}$ \\
\hline 0 & $12.2 \mathrm{ab}^{7}$ & $27.5 \mathrm{ab}$ & 30.8 & 27.5 & 39.8 & $20.2 \mathrm{a}$ & 19.5 & 6.7 & 11.2 & 1.3 \\
\hline 0.025 & $12.5 \mathrm{ab}$ & $27.4 \mathrm{ab}$ & 29.4 & 28.7 & 38.2 & $19.5 \mathrm{ab}$ & 18.7 & 7.0 & 10.7 & 1.3 \\
\hline 0.050 & $12.9 \mathrm{a}$ & $29.2 \mathrm{a}$ & 28.6 & 26.8 & 38.7 & $18.5 \mathrm{~b}$ & 20.2 & 6.3 & 11.9 & 0.9 \\
\hline 0.075 & $11.6 \mathrm{~b}$ & $26.8 \mathrm{~b}$ & 30.6 & 27.0 & 37.5 & $19.3 \mathrm{ab}$ & 18.2 & 8.3 & 11.1 & 1.6 \\
\hline SEM & 0.70 & 1.70 & 1.88 & 1.73 & 1.66 & 1.20 & 1.69 & 1.87 & 1.75 & 0.52 \\
\hline Probability & 0.005 & 0.04 & 0.08 & 0.09 & 0.06 & 0.04 & 0.11 & 0.22 & 0.52 & 0.06 \\
\hline
\end{tabular}

${ }^{1}$ Eviscerated weight after chilling for $24 \mathrm{~h}$.

${ }^{2}$ Includes breast meat (Fillet and Tender).

sIncludes thigh and drumstick meat.

Includes skins of breast, thighs and drumsticks.

Includes bones of breast, thighs and drumsticks.

${ }^{6}$ Includes the fat pad and the fat surrounding the internal organs.

'Within columns, means with different letters are significantly different $(\mathrm{P} \leq 0.05)$. 
that broilers fed diets with $0.10 \% \mathrm{AV}$ had higher dressing percentage at $42 \mathrm{~d}$ of age, but showed no improvement in deboned breastleg quarters or wing yields.

\section{CONCLUSIONS}

The only positive response in growth performance because of the addition of Avizyme to the diet of guinea broilers was the improvement in the FCR accompanying FI, whereas no improvements were found in BW at any of the three ages evaluated nor in processing yields The addition of $0.025 \%$ of Avizyme to diets might become a recommendable practice to improve the efficiency of feed utilization by guinea broilers if confirmed by additional research.

\section{LITERATURE CITED}

Avizyme 1500 Technical Bulletin, 2002. Danisco Animal Nutrition. St. Louis, Missouri, USA.

Café, M. B., C. A. Borges, C. A. Fritts and P. W. Waldroup, 2002. Avizyme improves performance of broilers fed corn-soybean meal-based diets. J. Appl. Poultry Res. 11:2933.

Douglas, M. W., C. M. Parsons and M. R. Bedford, 2000. Effect of various soybean meal sources and Avizyme on chick growth performance and ileal digestible energy . $J$. Appl. Poultry Res. 9:74-80.

Hughes, B. L. and J. E. Jones, 1980. Diet regimes for growing guineas as meat bird.Poultry Sci. 59: 582-584.

Mandal, A. B., N. N. Pathak and H. Singh, 1999. Energy and protein requirements of guinea keets (Numida meleagris) as meat bird in a hot humid c limate. J. Sci. Food Agric. 79: 523-531.

Oguntona, T. and A. K. Zubair, 1988. Response of guinea fowl (Numida meleagris) to dietary supplementation of zinc bacitracin. Poultry Sci. 67: 145-148.

Oguntona, T., M. Raheenat and A. K. Zubair, 1988. Effects of beak trimming at different ages on the body weight and feed conversion of guinea fowl ( Numida meleagris). Poultry Sci. 67: 141-144.

Waldroup, P. W., M. B. Café, C. A. Fritts and M. W. Greenwood, 2002. The Arkansas experience with Avizyme. Multi-state Poultry Meeting.

Wyatt, C., M. Soto-Salanova and M. Pack, 1997. Applying enzymes to sorghum based broiler diets. Proceedings of Aust. Poultry Sci. Symp. 9, Sydney Australia. PP 116118.

Zanella, L., N. K. Sakomura, F. G. Silversides, A. Fiqueirdo and M. Pack, 1999. Effect of enzyme supplementation of broiler diets based on corn and soybeans. Poultry Sci. 78:561-568. 